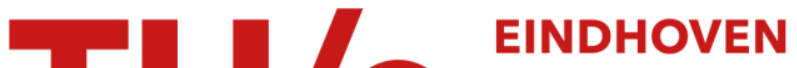 UNIVERSITY OF TECHNOLOGY
}

\section{Input Current Ripple Analysis of Six-Phase Full-Bridge Inverters}

Citation for published version (APA):

Arrozy, J., Huisman, H., \& Duarte, J. L. (2021). Input Current Ripple Analysis of Six-Phase Full-Bridge Inverters. In Proceedings of the Energy Conversion Congress and Exposition - Asia, ECCE Asia 2021 (pp. 131-136). [9479174] Institute of Electrical and Electronics Engineers. https://doi.org/10.1109/ECCEAsia49820.2021.9479174

DOI:

10.1109/ECCE-Asia49820.2021.9479174

Document status and date:

Published: $13 / 07 / 2021$

Document Version:

Accepted manuscript including changes made at the peer-review stage

Please check the document version of this publication:

- A submitted manuscript is the version of the article upon submission and before peer-review. There can be important differences between the submitted version and the official published version of record. People interested in the research are advised to contact the author for the final version of the publication, or visit the $\mathrm{DOI}$ to the publisher's website.

- The final author version and the galley proof are versions of the publication after peer review.

- The final published version features the final layout of the paper including the volume, issue and page numbers.

Link to publication

\section{General rights}

Copyright and moral rights for the publications made accessible in the public portal are retained by the authors and/or other copyright owners and it is a condition of accessing publications that users recognise and abide by the legal requirements associated with these rights.

- Users may download and print one copy of any publication from the public portal for the purpose of private study or research.

- You may not further distribute the material or use it for any profit-making activity or commercial gain

- You may freely distribute the URL identifying the publication in the public portal.

If the publication is distributed under the terms of Article $25 \mathrm{fa}$ of the Dutch Copyright Act, indicated by the "Taverne" license above, please follow below link for the End User Agreement:

www.tue.nl/taverne

Take down policy

If you believe that this document breaches copyright please contact us at:

openaccess@tue.nl

providing details and we will investigate your claim. 


\title{
Input Current Ripple Analysis of Six-Phase Full-Bridge Inverters
}

\author{
Juris Arrozy $^{1 *}$, Henk Huisman ${ }^{1}$, and Jorge L. Duarte ${ }^{1}$ \\ ${ }^{1}$ Electromechanics \& Power Electronics Group, Eindhoven University of Technology, The Netherlands \\ *j.arrozy@tue.nl
}

\begin{abstract}
This paper discusses the analytical expressions for the input current ripple of several six-phase full-bridge inverter topologies and their carrier-based PWM techniques. The analytical expressions are verified by simulation to prove their validity. A comparative analysis is performed to determine the effect of topologies and carrier-based PWM techniques on the input current ripple of the inverters.
\end{abstract}

Index Terms - input current ripple, multi-phase, fullbridge inverter, PWM technique.

\section{INTRODUCTION}

Multiphase machines have recently gained attention in several fields such as electric vehicles, electric ships, and more-electric aircrafts. This is mainly because of their inherent advantages such as power splitting, better faulttolerance, and lower torque ripple [1]. Another advantage is the reduced input current ripple. This is observed for instance in [2], where the results show that the battery current ripple is reduced with the phase number increase. In [3] it is also mentioned that the dc-bus capacitance requirement is decreased along with the phase number increase.

Open-winding multiphase machines propose a variant of multiphase machines, where the windings are left openended instead of being connected in delta or wye configuration and can therefore be driven independently. This results in better dc voltage utilization and faulttolerant capability at the cost of increased switch count [4]. Several topologies to drive the six-phase open-winding machine such as the six-phase full-bridge inverter [5], the dual supply six-phase full-bridge inverter [6], and the series connectable modular full-bridge inverter $[7,8]$ have been proposed.

Knowing the input current ripple of an inverter is essential for determining the dc link capacitor size. However, despite many attempts on deriving the input current ripple expression in the time $[9,10]$ and frequency [11] domain, so far their application to the multi-phase full-bridge inverter is limited. Attempts to derive the analytical expression for six-phase, nine-phase, and generalized multi-phase inverters were included in [1215], but only [13] covers the single supply open-winding machine (albeit only for the three-phase case). A mathematical analysis on the input current ripple of sixphase full-bridge inverters is still up for discussion.

Furthermore, whereas many modifications of the basic multi-phase full-bridge inverter topology such as the series-connectable modular full-bridge inverter and the dual-supply full-bridge inverter have been proposed, the concerns are limited to the fault-handling capability $[16,17]$, switch stressing [18], and dc voltage utilization [19]. Comparison of various multi-phase full-bridge inverter topologies in terms of their input current ripple has not been presented.

Therefore, this paper addresses the analytical expressions for the input current ripple of the six-phase full-bridge inverter, the dual supply six-phase full-bridge inverter, and the series connectable modular full-bridge inverter. In the six-phase full-bridge inverter case, various carrier-based PWM techniques such as phase-shifted and level-shifted are addressed besides the bipolar modulation for the multiple three-phase and symmetrical six-phase system. A comparative analysis is performed to determine the effect of topologies and PWM techniques to the input current ripple performance. The expressions are verified by simulation to prove their validity.

\section{SIX-Phase Full-Bridge INVERTERS}
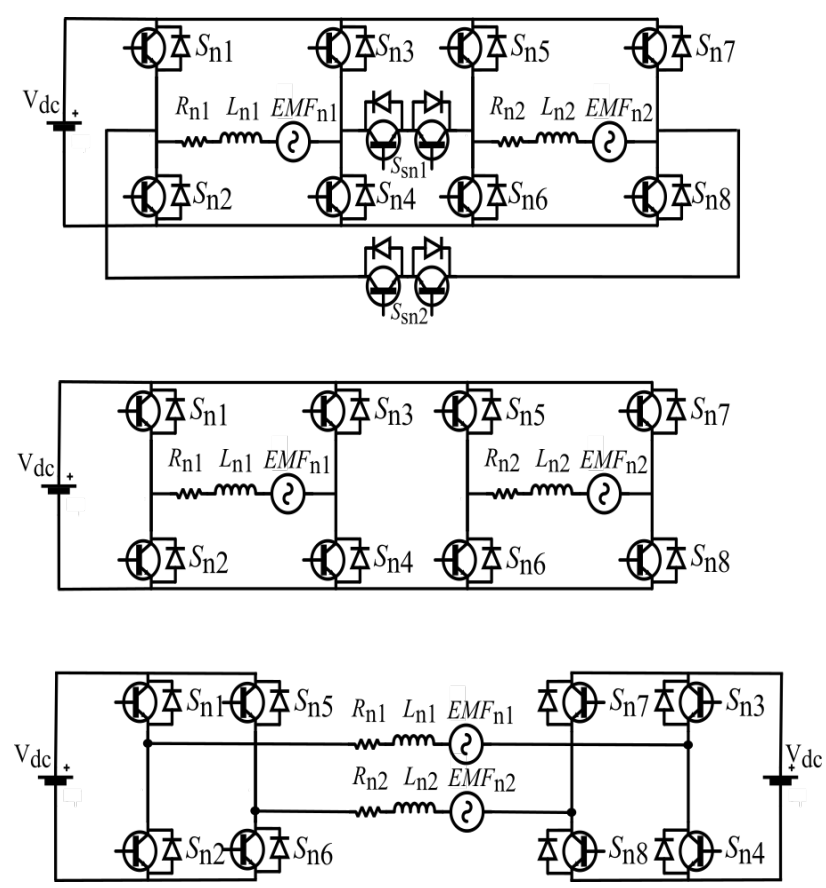

Fig. 1 Two-phase Representations of Six-Phase Full-Bridge Inverter Topologies: (a) Series Connectable Modular Full-Bridge Inverter (Top); (b) Six-Phase Full-Bridge Inverter (Middle); (c) Dual-Supply Six-Phase Full-Bridge Inverter (Bottom).

Fig. 1 depicts the six-phase inverters analyzed in this paper, where the subscript "n" denotes phase a, b, or c. The series connectable modular full-bridge inverter in Fig. 1a 
can be driven either in series configuration by connecting one of the series switches or in independent configuration by operating the full-bridge circuits separately. The transition from series to independent configuration and vice-versa is achieved by a changeover method based on the modulation index as proposed in [8]. When the modulation index reaches one, the circuit operation mode changes from the series to the independent configuration, with the modulation index applied to the independent circuits being half of the original one. When the modulation index again falls below one, the circuit returns to series configuration. To limit the amount of chattering between the two configurations, a small hysteresis is used for the change-over. In the implementation, a hysteresis is applied to prevent ringing between series and independent configuration. This is depicted in Fig. 2.

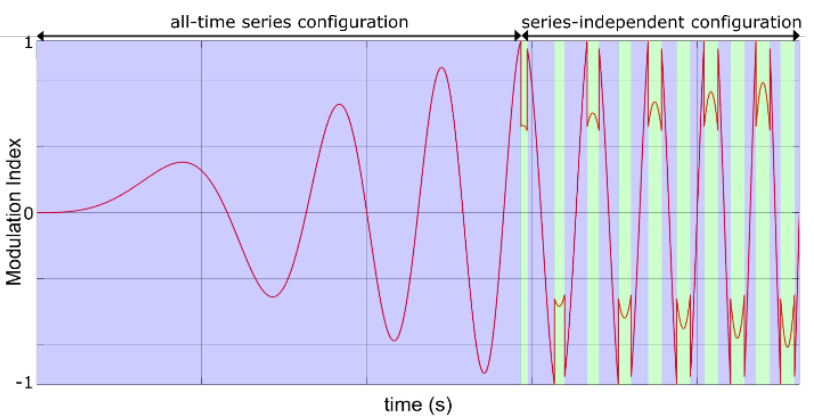

Fig. 2 Changeover Based On Modulation Index for the Series Connectable Modular Full-Bridge Inverter from [18].

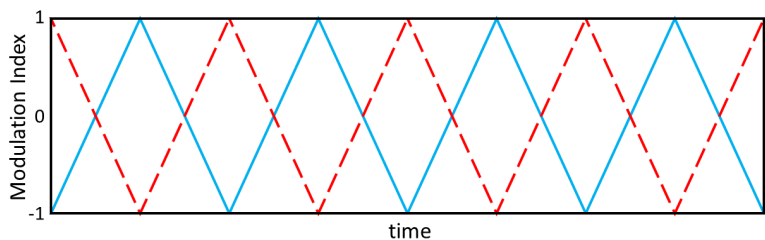

(a)

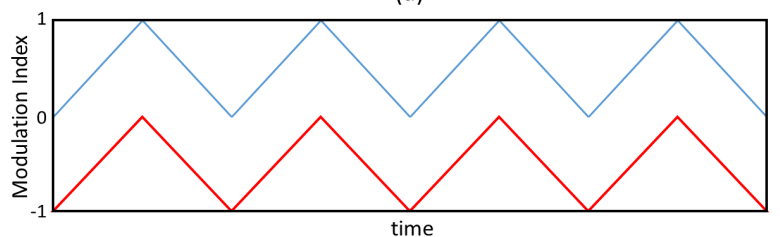

(b)

Fig. 3 (a) $180^{\circ}$ Phase-Shifted Carrier; (b) Level-Shifted Carrier.

The PWM technique used in the inverter affects its input current ripple. Therefore, for the six-phase fullbridge inverter, several PWM techniques are used: bipolar modulation, unipolar modulation, $180^{\circ}$ phase-shifted carrier-based PWM (Fig. 3a), and level-shifted carrierbased PWM (Fig. 3b). In addition, for the bipolar modulation, double three-phase and six-phase current phasors are both included. However, for the series connectable modular full-bridge inverter and dual supply six-phase full-bridge inverter, only bipolar modulation and the double three-phase system are utilized.
III. ANALYTICAL EXPRESSIONS FOR THE INPUT CURRENT RIPPLE

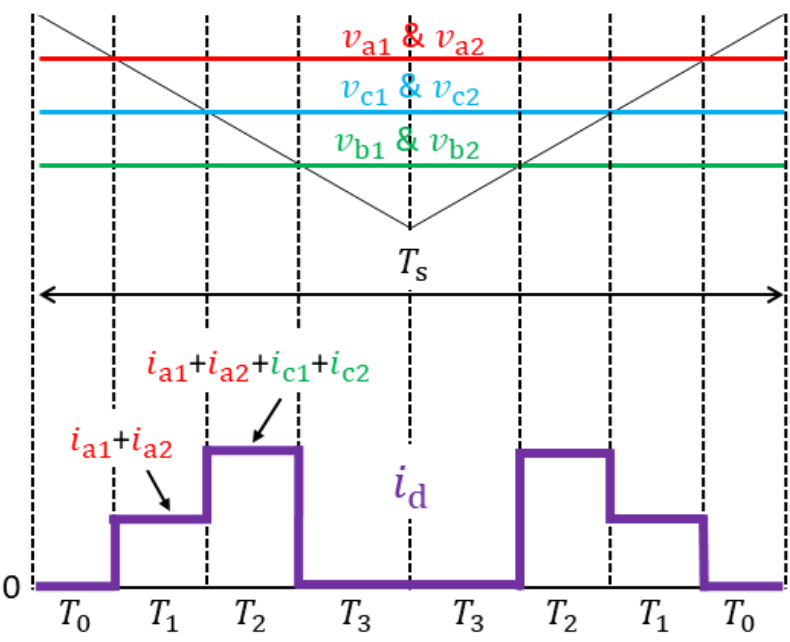

Fig. 4 PWM waveform and input current ripple over a single carrier period

The input current ripple expression derivations for the three-phase and general n-phase application has been featured in $[9,20]$. For this paper, the method will be extended to the full-bridge inverters under consideration.

Consider the double three-phase full-bridge inverter (Fig. 2b) under bipolar modulation. Assuming the carrier frequency is substantially higher than the ac frequency, the reference signals can be approximated as straight lines as in Fig. 4 for a single carrier period. Ignoring the output current ripple, this results in the input current as depicted on the bottom side of Fig. 4, where:

$$
\begin{aligned}
& v_{\mathrm{a} 1}=v_{\mathrm{a} 2}=m \sin (\omega t) \\
& v_{\mathrm{b} 1}=v_{\mathrm{b} 2}=m \sin (\omega t-2 \pi / 3) \\
& v_{\mathrm{c} 1}=v_{\mathrm{c} 2}=m \sin (\omega t+2 \pi / 3) \\
& i_{\mathrm{a} 1}=i_{\mathrm{a} 2}=\sqrt{2} I \sin (\omega t-\varphi) \\
& i_{\mathrm{b} 1}=i_{\mathrm{b} 2}=\sqrt{2} I \sin (\omega t-2 \pi / 3-\varphi) \\
& i_{\mathrm{c} 1}=i_{\mathrm{c} 2}=\sqrt{2} I \sin (\omega t+2 \pi / 3-\varphi)
\end{aligned}
$$

$m$ is the modulation index and $I$ is the rms phase current.

The intervals can be rewritten as:

$$
\begin{aligned}
& \frac{T_{0}}{T_{\mathrm{s}}}=\frac{1}{4}\left(1-\frac{v_{\mathrm{a} 1}}{V_{\mathrm{T}}}\right) \\
& \frac{T_{1}}{T_{\mathrm{s}}}=\frac{1}{4}\left(\frac{v_{\mathrm{a} 1}-v_{\mathrm{c} 1}}{V_{\mathrm{T}}}\right) \\
& \frac{T_{2}}{T_{\mathrm{s}}}=\frac{1}{4}\left(\frac{v_{\mathrm{c} 1}-v_{\mathrm{b} 1}}{V_{\mathrm{T}}}\right) \\
& \frac{T_{3}}{T_{\mathrm{s}}}=\frac{1}{4}\left(1+\frac{v_{\mathrm{b} 1}}{V_{\mathrm{T}}}\right)
\end{aligned}
$$

The input current over one carrier period can be formulated as follows: 


$$
i_{\mathrm{d}}=\left\{\begin{array}{c}
0 ; T_{0} \\
i_{\mathrm{a} 1}+i_{\mathrm{a} 2} ; T_{1} \\
0 ; T_{3}
\end{array}\right.
$$

The instantaneous value of the input current ripple over time is depicted in Fig. 4. Furthermore, the two phase sets produce identical currents in the respective phase. Taking that into account, the mean square value of the input current is obtained as:

$$
\begin{aligned}
I_{\mathrm{d}}{ }^{2} & =\frac{1}{T_{\mathrm{s}}} \int_{0}^{T_{\mathrm{s}}}{i_{\mathrm{d}}}^{2} d t \\
& =\frac{2 T_{1}}{T_{\mathrm{s}}}\left(4{i_{\mathrm{a}}}^{2}\right)+\frac{2 T_{1}}{T_{\mathrm{s}}}\left(4{i_{\mathrm{b}}}^{2}\right)
\end{aligned}
$$

Averaging the input current ripple over one-sixth of the fundamental frequency, the result is:

$$
\begin{aligned}
I_{\mathrm{d}, \text { avg }}{ }^{2} & =\frac{3}{\pi} \int_{\pi / 6}^{\pi / 2} I_{\mathrm{d}}^{2} d \theta \\
& =\frac{8 \sqrt{3} m I^{2}\left(4 \cos ^{2} \theta+1\right)}{\pi}
\end{aligned}
$$

where $\theta$ is the displacement angle between the current and the voltage.

The rms value of the ripple component can be obtained by subtracting (13) from the dc component of the input current ripple. This is shown in (14):

$$
\begin{aligned}
\widetilde{I}_{\mathrm{d}} & =\sqrt{I_{\mathrm{d}, \mathrm{avg}}^{2}-\bar{I}_{\mathrm{d}}^{2}} \\
& =\sqrt{\frac{8 \sqrt{3} m I^{2}\left(4 \cos ^{2} \theta+1\right)}{\pi}-\frac{36 m I^{2} \cos ^{2} \theta}{2}}
\end{aligned}
$$

where $\widetilde{I_{\mathrm{d}}}$ and $\overline{I_{\mathrm{d}}}$ are the ac and dc component of the input current, respectively.

The $I$ component in (14) can be normalized. Therefore, the final expression is only a function of $m$ and $\theta$. This is depicted in (15):

$$
\frac{\widetilde{I_{\mathrm{d}}}}{I}=\sqrt{\frac{8 \sqrt{3} m\left(4 \cos ^{2} \theta+1\right)}{\pi}-\frac{36 m \cos ^{2} \theta}{2}}
$$

By using the same procedures, the normalized input current ripple expression for other cases can be obtained. The final expressions for all cases are written as follows:

- Six-Phase Full-Bridge Inverter (Bipolar Modulation)

$$
\frac{\widetilde{I_{d}}}{I}=\sqrt{\frac{4 m\left(4(2+\sqrt{3})(\cos \varphi)^{2}+(-1+\sqrt{3})\right)}{\pi}-\frac{36 m^{2}(\cos \varphi)^{2}}{2}}
$$

- Double Three-Phase Full-Bridge Inverter (Bipolar Modulation)

$\frac{\widetilde{I_{\mathrm{d}}}}{I}=\sqrt{\frac{8 \sqrt{3} m\left(4 \cos ^{2} \theta+1\right)}{\pi}-\frac{36 m \cos ^{2} \theta}{2}}$

- Double Three-Phase Full-Bridge Inverter (Unipolar Modulation)

$\frac{\tilde{I_{d}}}{I}=\sqrt{\frac{4 m\left(4(2+\sqrt{3})(\cos \varphi)^{2}+(-1+\sqrt{3})\right)}{\pi}-\frac{36 m^{2}(\cos \varphi)^{2}}{2}}$

- Double Three-Phase Full-Bridge Inverter $\left(180^{\circ}\right.$ Phase-Shifted Carrier)

$\frac{\widetilde{I_{d}}}{I}=\sqrt{\frac{4 m\left(4(2+\sqrt{3})(\cos \varphi)^{2}+(-1+\sqrt{3})\right)}{\pi}-\frac{36 m^{2}(\cos \varphi)^{2}}{2}}$

- Double Three-Phase Full-Bridge Inverter (LevelShifted Carrier)

For $m \leq \frac{\sqrt{3}}{3}$,

$\frac{\widetilde{I_{d}}}{I}=\sqrt{\frac{4 \sqrt{3} m\left(4(\cos \varphi)^{2}+1\right)}{\pi}-\frac{36 m^{2}(\cos \varphi)^{2}}{2}}$

For $m \geq \frac{\sqrt{3}}{3}$,

$\frac{\widetilde{I_{d}}}{I}=\sqrt{a-b-\frac{36 m^{2}(\cos \varphi)^{2}}{2}}$

$a=\frac{\left(8 \sqrt{3-\frac{1}{m^{2}}}+4 \sqrt{3}\right) m\left(4(\cos \varphi)^{2}+1\right)}{\pi}$

$b=\frac{\left(\frac{16}{3 m} \sqrt{3-\frac{1}{m^{2}}} \cos ^{2} 2 \theta+24 \cos ^{-1} \frac{1}{\sqrt{3} m}\right)}{\pi}$

- Double Three-Phase Dual Supply Full-Bridge Inverter

$\frac{\tilde{I_{d}}}{I}=\sqrt{\frac{2 \sqrt{3} m\left(4(\cos \varphi)^{2}+1\right)}{\pi}-\frac{9 m^{2}(\cos \varphi)^{2}}{2}}$

- Double Three-Phase Series Connectable Modular Full-Bridge Inverter

For $m \leq 0.5$,

$\frac{\tilde{I_{d}}}{I}=\sqrt{\frac{2 \sqrt{3} m\left(4(\cos \varphi)^{2}+1\right)}{\pi}-\frac{9 m^{2}(\cos \varphi)^{2}}{2}}$ 
For $0.5 \leq m \leq 1 / \sqrt{3}$,

$$
\begin{aligned}
& \frac{\widetilde{I_{d}}}{I}=\sqrt{\frac{c+d}{2 \pi}-} \frac{9 m^{2}(\cos \varphi)^{2}}{2} \\
& c=-6 \alpha+3 \sin (2 \alpha-2 \theta) \\
& +4 m \cos (3 \alpha-2 \theta) \\
& +24 \sqrt{3} m+12 m \cos \alpha \\
& +24 m \cos (\alpha-2 \theta)
\end{aligned}
$$

$d=6 \beta-3 \sin (2 \beta-2 \theta)$

$$
\begin{aligned}
& -4 m \cos (3 \beta-2 \theta) \\
& -12 m \cos \beta \\
& -24 m \cos (\beta-2 \theta) \\
& +16 \sqrt{3} m \cos 2 \beta
\end{aligned}
$$

$\alpha=\sin ^{-1} \frac{1}{2 m}$

$\beta=\pi-\alpha$

For $1 / \sqrt{3} \leq m \leq 0.76$,

$$
\begin{aligned}
& \frac{\widetilde{I_{d}}}{I}=\sqrt{\frac{e+f}{4 \pi}-} \frac{9 m^{2}(\cos \varphi)^{2}}{2} \\
& e=4 \pi+8 m \cos (3 \gamma-2 \theta)+48 \sqrt{3} m \\
&-12 m \cos \gamma \\
&-24 m \cos (\gamma-2 \theta) \\
&+6 \sqrt{3} \cos \left(2 \theta-2 \gamma+\frac{\pi}{3}\right) \\
&+12 \sqrt{3} m \sin \gamma \\
&+24 \sqrt{3} m \sin (\gamma-2 \theta) \\
&+2 m \cos 2 \theta
\end{aligned}
$$

$$
\begin{aligned}
f=-8 m \cos (3 \delta & -2 \theta)+12 m \cos \delta \\
& +24 m \cos (\delta-2 \theta) \\
& +6 \sqrt{3} \cos \left(2 \delta-2 \theta+\frac{\pi}{3}\right) \\
& +12 \sqrt{3} m \sin \delta \\
& +24 \sqrt{3} m \sin (\delta-2 \theta)
\end{aligned}
$$

$$
\gamma=\sin ^{-1} \frac{-1}{2 m}+2 \pi / 3
$$$$
\delta=\pi-\gamma
$$

For $0.76 \leq m \leq 1$,

$$
\frac{\tilde{I_{d}}}{I}=\sqrt{\frac{g+h}{4 \pi}-\frac{9 m^{2}(\cos \varphi)^{2}}{2}}
$$

$$
\begin{aligned}
g=4 \pi+8 m \cos & (3 \varepsilon-2 \theta)+48 \sqrt{3} m \\
& +24 m \cos \varepsilon-36 m \cos \gamma \\
& -24 m \cos (\varepsilon-2 \theta) \\
& +6 \sqrt{3} \cos \left(2 \theta-2 \gamma+\frac{\pi}{3}\right) \\
& +72 \sqrt{3} m \sin \varepsilon \\
& -60 \sqrt{3} m \sin \gamma \\
& +72 \sqrt{3} m \sin (\varepsilon-2 \theta) \\
& -48 \sqrt{3} m \sin (\gamma-2 \theta) \\
& +32 \sqrt{3} m \cos 2 \theta \\
& +24 \sqrt{3} m \sin (3 \varepsilon-2 \theta) \\
& -24 \sqrt{3} \sin (3 \gamma-2 \theta) \\
h=-8 m \cos (3 \epsilon & -2 \theta)-24 m \cos \epsilon \\
& +36 m \cos \delta \\
& +24 m \cos (\epsilon-2 \theta) \\
& +6 \sqrt{3} \cos \left(2 \delta-2 \theta+\frac{\pi}{3}\right) \\
& +72 \sqrt{3} m \sin \epsilon \\
& -60 \sqrt{3} m \sin \delta \\
& +72 \sqrt{3} m \sin (\varepsilon-2 \theta) \\
& +48 \sqrt{3} m \sin (\delta-2 \theta) \\
& +24 \sqrt{3} m \sin (3 \epsilon-2 \theta) \\
& -24 \sqrt{3} \sin (3 \delta-2 \theta) \\
\varepsilon=1.38(\mathrm{rad}) & \\
\epsilon=\pi-\varepsilon &
\end{aligned}
$$

It is to be noted that in order to achieve a fair comparison, the modulation index in the series connectable modular full-bridge inverter is half of the other inverters. This is because for the same value of phase current, the modulation index needed to produce it in series configuration is half of the other inverters.

The unipolar modulation, $180^{\circ}$ phase-shifted carrier, and six-phase bipolar modulation provide the same results. This is because in unipolar modulation, additional threephase reference signals $180^{\circ}$ apart from the original reference signals are used. This makes the inverter behave as if the current phasors applied are the balanced six-phase one seen from the input side. The $180^{\circ}$ phase-shifted carrier modulation method also produces a similar effect due to the presence of interleaved carriers.

\section{Simulation Results}

TABLE I

SYSTEM PARAMETERS

\begin{tabular}{|c|c|}
\hline Parameters & Values \\
\hline dc Voltage & $320 \mathrm{~V}$ \\
\hline Inductance & $2.6 \Omega$ \\
\hline Resistance & $33 \mathrm{mH}$ \\
\hline$\theta$ (displacement angle) & $1.11 \mathrm{rad}$ \\
\hline
\end{tabular}




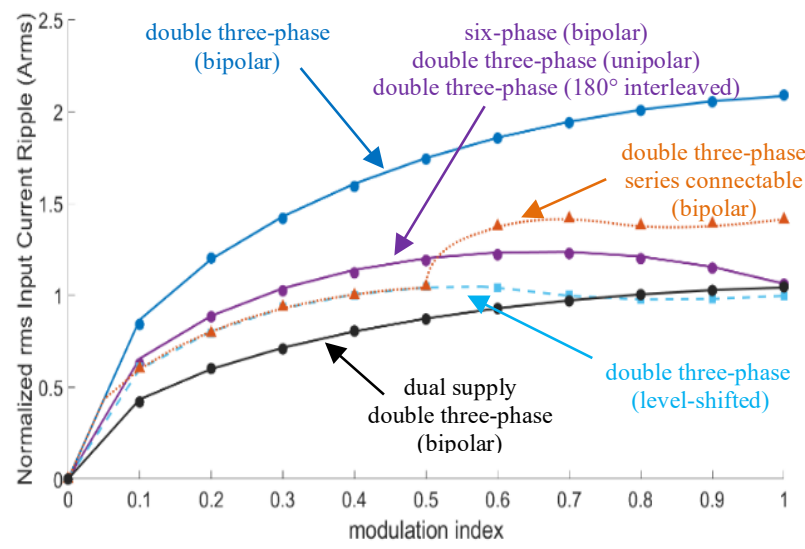

Fig. 5 Comparison between the Simulation (dot) and Analytical (line) Results.

Table I shows the system parameters, while Fig. 5 depicts the comparison between the simulation and analytical results for the inverters under consideration. It is shown that the analytical expressions match the simulated value.

It is also shown that by changing the PWM technique, the same inverter can produce different input current ripple performance. This is shown by the comparison between double three-phase bipolar, double three-phase unipolar, six-phase bipolar, and double three-phase level-shifted. It is shown that the level-shifted modulation produces the lowest input current ripple among other methods. This is because in the level-shifted modulation, both the high side or low side switches pair of the full-bridge module turn on more often, creating a circulation in the phase current which does not add up to the input current.

The dual supply double three-phase full-bridge inverter produces half the input current of its single supply counterpart. This is because in the dual supply full-bridge inverter, there are two dc supplies isolated from each other. Therefore, the input current ripple is divided between the two capacitors. This is advantageous in splitting the capacitor stress between the two capacitors, therefore reducing their required size. However, this comes at a price of having to provide two isolated dc supplies, which may not be practical in some applications.

For the series connectable modular full-bridge inverter, it is shown that for $m>0.5$, the input current ripple increases significantly. This can be explained by resorting to the inverter's operating mode. In series configuration, the two windings are connected by a series switch, and only four main switches are operating - forming a fullbridge. This is advantageous from the input current ripple side because the two windings of the same phase are connected in series. Therefore, the current flowing from the input side to the windings is $i$ as opposed to $2 i$ when the two windings are driven independently. This comes at a price of higher modulation index (two times the independent operation). However, from (12) it is implied that the role of current is greater than the modulation index in determining the input current ripple. This is because in the equation, the current is squared while the modulation index is linear.

\section{CONCLUSIONS}

This paper derives the equations for the input current ripple for several six-phase full-bridge inverter topologies, namely the single supply full-bridge inverter, the dual supply full-bridge inverter, and the series connectable modular full-bridge inverter. The analytical expressions are verified by simulation. It is shown that for the same topology, i.e. single supply full-bridge inverter, changing the PWM technique affects the performance of the input current ripple.

It is also shown that the dual supply topology's current ripple is half of its single supply counterpart due to the current ripple sharing between the two capacitors. However, the expense is the need of two isolated dc supplies which may not be practical for some applications. For the series connectable modular full-bridge inverter, when the modulation index is above 0.5 , its input current ripple starts to increase because the two windings of the same phase are driven independently, adding to the total current flowing from the input side.

\section{ACKNOWLEDGMENT}

This paper is part of the ModulED project that has received funding from the European Union's Horizon 2020 research and innovation program under grant agreement No 79953.

\section{REFERENCES}

[1] F. Barrero and M. J. Duran, "Recent Advances in the Design, Modeling, and Control of Multiphase MachinesPart I," in IEEE Transactions on Industrial Electronics, vol. 63, no. 1, pp. 449-458, Jan. 2016.

[2] L. Jin, S. Norrga, H. Zhang and O. Wallmark, "Evaluation of a multiphase drive system in EV and HEV applications," 2015 IEEE International Electric Machines \& Drives Conference (IEMDC), Coeur d'Alene, ID, 2015, pp. 941945.

[3] A. Salem and M. Narimani, "A Review on Multiphase Drives for Automotive Traction Applications," in IEEE Transactions on Transportation Electrification, vol. 5, no. 4, pp. 1329-1348, Dec. 2019.

[4] Z. Liu, Y. Li and Z. Zheng, "A review of drive techniques for multiphase machines," in CES Transactions on Electrical Machines and Systems, vol. 2, no. 2, pp. 243-251, June 2018

[5] M. Mekasser, Q. Gao and C. Xu, "Common mode voltage elimination in dual-inverter-fed six-phase open-end winding PMSM drives with a single DC supply," in The Journal of Engineering, vol. 2019, no. 17, pp. 3598-3602.

[6] M. Jones, F. Patkar and E. Levi, "Carrier-based pulse-width modulation techniques for asymmetrical six-phase open-end winding drives," in IET Electric Power Applications, vol. 7 , no. 6, pp. 441-452, July 2013.

[7] T. Gerrits, C. G. E. Wijnands, J. J. H. Paulides and J. L. Duarte, "Fault-Tolerant Operation of a Fully Electric Gearbox Equivalent," in IEEE Transactions on Industry Applications, vol. 48, no. 6, pp. 1855-1865, Nov.-Dec. 2012.

[8] B. Daniels, J. Gurung, H. Huisman and E. A. Lomonova, "Feasibility Study of Multi-Phase Machine Winding Reconfiguration for Fully Electric Vehicles," 2019 Fourteenth International Conference on Ecological Vehicles 
and Renewable Energies (EVER), Monte-Carlo, Monaco, 2019, pp. 1-6.

[9] P. A. Dahono, Y. Sato and T. Kataoka, "Analysis and minimization of ripple components of input current and voltage of PWM inverters," in IEEE Transactions on Industry Applications, vol. 32, no. 4, pp. 945-950, July-Aug. 1996.

[10] J. W. Kolar and S. D. Round, "Analytical calculation of the RMS current stress on the DC-link capacitor of voltagePWM converter systems," in IEE Proceedings - Electric Power Applications, vol. 153, no. 4, pp. 535-543, July 2006.

[11] B. P. McGrath and D. G. Holmes, "A General Analytical Method for Calculating Inverter DC-Link Current Harmonics," in IEEE Transactions on Industry Applications, vol. 45, no. 5, pp. 1851-1859, Sept.-oct. 2009.

[12] P. A. Dahono and A. Satria, "Input current ripple analysis of inverter fed dual three-phase Ac motors," 2014 International Power Electronics Conference (IPEC-Hiroshima 2014 ECCE ASIA), Hiroshima, 2014, pp. 3893-3897.

[13] P. A. Dahono, A. Satria and D. Nurafiat, "Analysis of DC current ripple in six-legs twelve-devices inverters," 2012 International Conference on Power Engineering and Renewable Energy (ICPERE), Bali, 2012, pp. 1-6.

[14] D. Nurafiat and P. A. Dahono, "Input current ripple analysis of nine-phase PWM inverters," IECON 2011 - 37th Annual Conference of the IEEE Industrial Electronics Society, Melbourne, VIC, 2011, pp. 1378-1383.

[15] A. Muqorobin, P. A. Dahono and A. Purwadi, "Optimum phase number for multiphase PWM inverters," 2017 4th International Conference on Electrical Engineering, Computer Science and Informatics (EECSI), Yogyakarta, 2017, pp. 1-6.

[16] J. Arrozy, D. V. Retianza, J. L. Duarte and H. Huisman, "Fault-Tolerant Control of Series Connectable Modular Full-Bridge Inverter Mitigating Open Switch Faults," 2020 22nd European Conference on Power Electronics and Applications (EPE'20 ECCE Europe), Lyon, France, 2020, pp. P.1-P.9.

[17] J. Hemsen, D. Kieninger, L. Eckstein, M. R. Lidberg, H. Huisman, J. Arrozy, E. A. Lomonova, D. Oeschger, C. Lanneluc, O. Tosoni, P. Debal, M. Ernstorfer and R. Mongellaz, "'Innovative and highly integrated modular electric drivetrain," World Electric Vehicle Journal, vol. 10, no. 4, 2019.

[18] J. Arrozy, H. Huisman, J. L. Duarte and E. A. Lomonova, "A Heuristic Method to Improve Power Cycling Related Lifetime in Series Connectable Modular Full-Bridge Inverter," 2020 Fifteenth International Conference on Ecological Vehicles and Renewable Energies (EVER), Monte-Carlo, Monaco, 2020, pp. 1-9.

[19] F. Patkar, E. Levi and M. Jones, "A six-phase multilevel space vector PWM algorithm for a dual-inverter supplied drive," 6th IET International Conference on Power Electronics, Machines and Drives (PEMD 2012), Bristol, 2012, pp. 1-5.

[20] A. Muqorobin \& P.A. Dahono, "Input Current Ripple Analysis of Multiphase PWM Inverters," in International Journal of Power Electronics and Drive System (IJPEDS), vol. 9, no. 3, pp. 1432-1444, September 2018. 